\title{
Quantifying chelonid herpesvirus 5 in symptomatic and asymptomatic rehabilitating green sea turtles
}

\author{
Annie Page-Karjian ${ }^{1, *}$, Terry M. Norton ${ }^{2}$, Branson Ritchie $^{3}$, Corrie Brown' ${ }^{1}$, \\ Carmen Mancia ${ }^{4}$, Mark Jackwood ${ }^{5}$, Nicole L. Gottdenker ${ }^{1}$ \\ ${ }^{1}$ Department of Pathology, College of Veterinary Medicine, University of Georgia, Athens, GA 30602, USA \\ ${ }^{2}$ Georgia Sea Turtle Center, Jekyll Island Authority, Jekyll Island, GA 31527, USA \\ ${ }^{3}$ Infectious Diseases Laboratory, College of Veterinary Medicine, University of Georgia, Athens, GA 30602, USA \\ ${ }^{4}$ School of Veterinary Medicine, St. George's University, St. George's, Grenada \\ ${ }^{5}$ Poultry Diagnostic and Research Center, University of Georgia, Athens, GA 30602, USA
}

\begin{abstract}
Fibropapillomatosis (FP), an infectious disease of sea turtles, is characterized by tumors of the skin, eye(s) and/or internal organ(s), and is associated with chelonid herpesvirus 5 (ChHV5). Despite extensive research on FP, the pathogenesis of ChHV5 remains poorly understood, particularly regarding asymptomatic infections. Here, we provide evidence for detectable ChHV5 DNA in biological samples from symptomatic and asymptomatic green turtles Chelonia mydas. Using a probe-based quantitative PCR (qPCR) assay for ChHV5, we evaluated the relationship between ChHV5 DNA loads and FP disease status, and investigated potential routes of ChHV5 shedding. Samples of tissue, blood, urine, and feces were collected from 67 green turtles at 3 rehabilitation facilities in the southeastern USA. Turtles were divided into 3 study groups: clinical signs of FP $(\mathrm{n}=23)$, history of FP but no clinical signs $(\mathrm{n}=13)$, and no known history of FP ( $\mathrm{n}=31$ ). Via qPCR, ChHV5 DNA was reliably detected in FP tumors, non-tumored skin, blood, urine, cloacal swabs, and plasma from green turtles in all 3 groups. Our results provide novel evidence for ChHV5 DNA in blood cells, which may represent a critical phase of the ChHV5 life cycle and provide a mechanism for viral transport, and documents that viral DNA can be detected in the urine of symptomatic and asymptomatic turtles. As molecular diagnostics become more affordable, sea turtle health experts can use qPCR to monitor ChHV5 gene copies and thereby detect early signs of viral presence in blood, urine, and tissue samples.
\end{abstract}

KEY WORDS: Chelonia mydas · ChHV5 - Fibropapillomatosis · Herpesvirus · Quantitative PCR · Subclinical viral infection

\section{INTRODUCTION}

Fibropapillomatosis (FP) is an infectious disease of sea turtles with both individual and population level effects (Aguirre \& Lutz 2004). FP tumors, characterized by growths on the skin, shell(s), eye(s), and/or internal organs, often debilitate affected turtles by obstructing feeding and movement, obscuring vision, and/or leading to organ failure (Balazs 1989, Herbst 1994). FP has been reported in all sea turtle species, but it has reached epizootic status in green turtles Chelonia mydas in several locations worldwide, and is also being

\footnotetext{
*Corresponding author: anniep@uga.edu
}

reported from new localities around the world (Williams et al. 1994, Huerta et al. 2002, Hirama \& Ehrhart 2007, Chaloupka et al. 2009, Tristan et al. 2010, Duarte et al. 2012). FP primarily affects juvenile turtles after they have migrated to near-shore habitats (Ene et al. 2005). In sea turtle rehabilitation centers, FP is a key concern because it requires extensive quarantine measures and complicates prognoses, and, in some cases, FP tumors develop after turtles are admitted for other reasons (Page-Karjian et al. 2014).

Chelonid herpesvirus 5 (ChHV5; genus Scutavirus; Adams \& Carstens 2012) has been consistently iden-

() The authors 2015. Open Access under Creative Commons by Attribution Licence. Use, distribution and reproduction are unrestricted. Authors and original publication must be credited. 
tified in FP tumors via molecular tests such as polymerase chain reaction (PCR; Lackovich et al. 1999, Quackenbush et al. 2001, Ene et al. 2005), although Koch's postulates have not been fulfilled due to an inability to culture the virus to date (Moore et al. 1997, Lu et al. 1999, Work et al. 2009). In addition to identification of ChHV5 in tumors, ChHV5 DNA has also been identified in tissues of apparently healthy turtles via PCR, suggesting the detection of early, subclinical or latent viral infection (Quackenbush et al. 2001, Page-Karjian et al. 2012, Alfaro-Núñez \& Gilbert 2014).

Genomic analyses of reptilian herpesvirus sequences suggest that ChHV5 should be grouped among the alphaherpesviruses (McGeoch et al. 2005, 2006, Davison et al. 2009), although ChHV5 also harbors at least 4 genes that are more typical of beta- and gammaherpesvirinae (Ackermann et al. 2012). Regardless of subfamily, most herpesviruses establish a post-inoculation systemic infection accompanied by a cell-associated viremia (virus present in the blood). In infected individuals, viremia is usually indicative of viral replication, and can be detectable during either the primary infection event or during viral reactivation following a period of latency (Paillot et al. 2008).

Reptilian herpesviruses are commonly transmitted after establishment of primary infection or after induction of latent infections with periodic viral shedding following stressful factors such as concomitant disease, malnutrition, environmental stress such as temperature changes (high or low), movement of animals, introduction of new animals to an established collection, or breeding activity. Virus shedding may or may not be associated with concurrent signs of disease (Ritchie 2006). A horizontal route of transmission by ChHV5 was demonstrated when cell-free skin tumor extract inoculates were shown to transmit FP to uninfected turtles (Herbst et al. 1995). The primary target of ChHV5 seems to be skin, and infection is thought to be transmitted by sloughing of virally infected epidermal cells into the environment (Herbst et al. 1995, 1999, Work et al. 2014). However, an 83.6\% seroprevalence of ChHV5 glycoprotein $\mathrm{H}$ antibodies was observed in a green turtle aggregation that had no signs of FP tumors (Herbst et al. 2008), suggesting that there may be alternate viral transmission cycles involving virus replication and shedding from tissues other than skin tumors. Determining how ChHV5 is transmitted in apparently healthy FP-free populations could have major implications in designing effective prevention and disease control strategies (Herbst et al. 2008). Recently, a nested PCR assay identified ChHV5 DNA in $32.4 \%$ of skin samples taken from tu- mor-free, wild-caught green turtles in Puerto Rico, suggesting that these asymptomatic turtles may be capable of shedding viral DNA from normal skin (Page-Karjian et al. 2012). Such asymptomatic turtles may remain disease-free or may experience a transient viral incubation phase followed later by clinical signs (FP tumors). Intermittent viral shedding by subclinically infected sea turtles, whether via skin or other routes, could explain spontaneous FP infections in established turtle colonies and suggest an additional mechanism for viral transmission between turtles under natural conditions.

The pathogenesis of ChHV5 is poorly understood, particularly with regards to detection of viral DNA in asymptomatic turtles. For example, data are lacking regarding viral loads in various fluid and tissue samples during the course of infection with ChHV5associated disease. Viral load data are routinely used in the clinical management of human and animal herpesvirus-associated diseases, particularly for the prevention, diagnosis, and monitoring of herpesvirusassociated tumors and proliferative blood cell disorders (e.g. Gärtner \& Preiksaitis 2010, Stanton et al. 2013), and are thus of great potential relevance for sea turtle FP. Quantitative PCR (qPCR) technology is a flexible, rapid, sensitive, specific, and quantitative method that can be used to measure viral DNA in diverse clinical and research settings (Mackay 2004). Using qPCR, viral DNA kinetics can be evaluated and compared for symptomatic and asymptomatic infected turtles, helping to predict disease outbreaks, explain differences in disease states, and improve transmission risk management (e.g. Yamamoto et al. 2014).

Sea turtle rehabilitation facilities offer unique opportunities to access and observe wild sea turtles in a controlled setting. In this study, we (1) developed and validated a qPCR assay for the detection and quantification of ChHV5 DNA, in order to (2) evaluate the relationship between ChHV5 DNA loads and clinical disease in rehabilitating green turtles, and (3) investigate potential routes of ChHV5 DNA shedding by symptomatic and asymptomatic turtles.

\section{MATERIALS AND METHODS}

\section{Study design and biological sample collection}

Sixty-seven green turtles were divided into 3 study groups based on clinical signs and history at the time of sampling: Group A - turtles with clinical signs of FP ( $\mathrm{n}=23)$, Group B - turtles with a history of FP but 
with no clinical signs (i.e. turtles that previously had FP tumors surgically removed; $\mathrm{n}=13$ ), and Group C - turtles with no known history of FP $(\mathrm{n}=31)$. Biological samples were collected from juvenile green turtles at 3 rehabilitation facilities in the southeastern USA - the Georgia Sea Turtle Center, Jekyll Island, Georgia; the Loggerhead Marinelife Center, Juno Beach, Florida; and The Turtle Hospital, Marathon, Florida. As negative controls, samples were collected from 1 green turtle with no known history of FP raised in a captive breeding facility where FP has not been observed in >30 yr and from 2 adult female freshwater turtles (Trachemys scripta elegans) raised in a captive breeding facility in the southeastern USA.

\section{Blood}

Venipuncture sites were swabbed with sterile povidone iodine followed by $70 \%$ alcohol prior to needle insertion. Using heparinized, 3 or $6 \mathrm{ml}$ syringes and 21 to 25 gauge, 1 to 1.5 inch needles (depending on the turtle's size), 3 to $6 \mathrm{ml}$ of blood was collected aseptically into lithium heparin $(\mathrm{LiH})$ tubes from the dorsal cervical sinus of each turtle. Aliquots $(0.2$ to $1.0 \mathrm{ml}$ ) of fresh whole blood were placed into $1.5 \mathrm{ml}$ cryotubes. The remaining blood samples were centrifuged in the $\mathrm{LiH}$ tubes at $2500 \mathrm{rpm}(664 \times \mathrm{g})$ for $10 \mathrm{~min}$. Separated plasma samples were then placed into $1.5 \mathrm{ml}$ cryotubes. Blood and plasma samples were stored at $-80^{\circ} \mathrm{C}$ for up to 3 mo prior to analysis.

\section{FP tumors}

$\mathrm{CO}_{2}$ laser-mediated surgery was used to remove FP tumor samples from FP+ turtles. Varying levels of power, pulse rate, and hand piece size were used depending on the surface area extent and depth of FP. All tumors were removed in 1 surgical procedure per turtle, and procedures lasted a maximum of $2.5 \mathrm{~h}$. A 2 to $5 \mathrm{~cm}$ diameter portion of each tumor sample was placed into a tissue cassette and then into $10 \%$ buffered formalin for up to $10 \mathrm{~d}$; this was followed by routine preparation for histological examination (University of Georgia, Veterinary Diagnostic and Investigational Laboratory [UGA VDIL]). The prepared histological slides were evaluated to confirm the morphologic diagnosis of FP. Remaining tumor samples were placed into either $1.5 \mathrm{ml}$ cryotubes or Whirlpak ${ }^{\circledR}$ bags and stored at $-80^{\circ} \mathrm{C}$ for up to $3 \mathrm{mo}$ prior to analysis.

\section{Non-tumored skin biopsies}

Following preparation of the biopsy site with Betadine ${ }^{\circledR}$ scrub and $70 \%$ ethyl alcohol, and subcutaneous injection of $2 \%$ lidocaine solution $\left(5 \mathrm{mg} \mathrm{kg}^{-1}\right.$ mixed 1:1 with sodium bicarbonate $\left[1 \mathrm{mEq} \mathrm{ml}{ }^{-1}\right]$; PennVet), skin biopsies were aseptically collected from the left or right shoulder using a sterile, disposable $4 \mathrm{~mm}$ biopsy punch. Biopsy sites were left open to heal by secondary intention. Healing was generally rapid $(<2 \mathrm{wk})$; biopsy sites were routinely cleaned until healed, using silver sulfadiazine cream on the wounds as needed. Skin biopsy samples were sectioned in half using a sterile scalpel blade (No. 10): half of each sample was placed into a $1.5 \mathrm{ml}$ cryotube and stored at $-80^{\circ} \mathrm{C}$ for up to 3 mo prior to analysis; the other half was placed in a tissue cassette and then into $10 \%$ buffered formalin for up to $10 \mathrm{~d}$; this was followed by routine preparation for histological examination (UGA VDIL). The prepared histological slides were evaluated microscopically to confirm the absence of FP.

\section{Urine}

Urine samples (1 to $30 \mathrm{ml}$ ) were opportunistically collected into sterile, $118 \mathrm{ml}$ urine cups as turtles were handled for rehabilitation purposes (i.e. physical therapy, shell treatment, diagnostic imaging, medication administration, etc.). Turtles were allowed to air-dry prior to urine collection to prevent tankwater contamination of urine samples. After collection, urine samples were transferred into $60 \mathrm{ml}$ Eppendorf tubes. Tubes were sealed with Parafilm ${ }^{\circledR}$ and stored at $-80^{\circ} \mathrm{C}$ for up to 3 mo prior to analysis.

\section{Feces}

Fecal samples (up to $1 \mathrm{~g}$ ) were opportunistically collected from the turtles' tanks within $4 \mathrm{~h}$ after defecation, placed into Whirlpak ${ }^{\circledR}$ bags, and stored at $-80^{\circ} \mathrm{C}$ for up to $3 \mathrm{mo}$ prior to analysis.

\section{Oral and cloacal swabs}

Oral and cloacal mucosal swabs were collected by swabbing buccal and cloacal mucosae with separate, sterile cotton-tipped swabs for 5 to $10 \mathrm{~s}$, using moderate pressure to collect epithelial cells. Swab tips were immediately placed into cryotubes and stored at $-80^{\circ} \mathrm{C}$ for up to $3 \mathrm{mo}$ prior to analysis. 


\section{Nucleic acid extraction}

Genomic DNA (gDNA) was extracted from each sample using the appropriate kits (Qiagen): DNeasy Blood and Tissue Kit for blood, non-tumored skin, and FP samples; MinElute Virus Spin Kit for plasma, oral swabs, and cloacal swabs; QIAamp DNA Stool Mini Kit for feces; and QIAamp Viral RNA Kit for urine. To normalize samples prior to $\mathrm{qPCR}$, the concentration of the extracted DNA $\left(\mu g \mu^{-1}\right)$ in each sample was measured using absorbance spectrophotometry (Nanodrop), and ratios of absorption at $260 \mathrm{~nm}$ versus $280 \mathrm{~nm}$ were evaluated to ensure DNA purity. Extracted DNA was stored at $-20^{\circ} \mathrm{C}$ for up to $3 \mathrm{mo}$ prior to qPCR analysis.

\section{ChHV5-specific qPCR development}

To quantify ChHV5 DNA loads in various green turtle biological samples, we developed a probebased qPCR assay based on the highly conserved DNA polymerase region (UL30) of the ChHV5 genome. Reaction efficiency and precision were demonstrated using a plasmid standard curve.

\section{Primer and probe design and optimization}

Prospective primers were designed based on a consensus sequence using all currently available sequence data of the UL30 region of the ChHV5 genome (GenBank). Consensus sequence development, performed using Clustal Omega multiple sequence alignment software (EMBL-EBI) and CLC Bio Main Workbench 6 (Qiagen), selectively included UL30 sequences isolated from green turtle isolates and excluded UL30 sequences isolated from other sea turtle species to increase assay specificity. The forward and reverse primer sequences selected using Primer3Plus software (Rozen \& Skaletsky 2000; Table 1) amplify a $173 \mathrm{bp}$ fragment of the ChHV5 UL30 gene. A primer matrix was used to determine optimal primer concentrations: $0.32 \mu \mathrm{M}$ for both forward and reverse primers was chosen, based on the low cycle quantification $\left(\mathrm{C}_{\mathrm{q}}\right)$ value (Bustin et al. 2009) and reduced primer concentration (Stratagene 2004). Assay specificity was improved via use of a dual-labeled hydrolysis probe unique to ChHV5 UL30 DNA, developed using Primer3Plus software (Rozen \& Skaletsky 2000). The selected probe was synthesized with a 6-FAM (fluorescein) fluorescent dye and a ZEN internal quencher (Table 1). Probe concentration $(0.32 \mu \mathrm{M})$ selection was the lowest yielding acceptable detection. The primers and probe were manufactured by Integrated DNA Technologies (IDT). A melt curve analysis performed using SYBR Green chemistry $\left(95^{\circ} \mathrm{C}\right.$ for $10 \mathrm{~min}, 60$ to $95^{\circ} \mathrm{C}$ incremented stepwise by $5^{\circ} \mathrm{C}$ per $30 \mathrm{~s})$ was used to confirm amplification of a single product and ensure the absence of amplification artifacts (Bustin \& Nolan 2004). Sanger sequencing, Basic Local Alignment Search Tool (BLAST) software (Altschul et al. 1990), and Clustal Omega multiple sequence alignment software (EMBL-EBI) were used to confirm qPCR product identity during assay development $(100 \%$ sequence identity to chelonid herpesvirus 5 partial genome; GenBank HQ878327.2). To demonstrate the presence of amplifiable DNA, primers developed and optimized for Chelonia mydas $\beta$-actin and glyceraldehyde 3-phosphate dehydrogenase (GAPDH) gene segments (Table 1; GenBank AY373753.1 and FJ234450.1, respectively) were applied to all samples and included in all qPCR runs.

\section{Construction of a ChHV5 plasmid DNA standard curve for qPCR}

The ChHV5 UL30 standard curve was constructed by first cloning a $173 \mathrm{bp}$ fragment amplified with the qPCR primers described in the preceding subsection into the pGEM-T Easy Vector (Promega). The plasmid was linearized using the EcoRV enzyme, and the product obtained was sequenced to confirm identity. The 3173 bp plasmid containing the target ChHV5

Table 1. Primers and probe sequences used in qPCR assay for the highly conserved DNA polymerase region of the chelonid herpesvirus 5 genome (ChHV5 UL30) and Chelonia mydas genes. GAPDH: glyceraldehyde 3-phosphate dehydrogenase

\begin{tabular}{|c|c|}
\hline Sequence identifier & Sequence \\
\hline ChHV5 UL30, forward primer & 5'-AAC GCT TGC TTT TGG ACA AG-3' \\
\hline ChHV5 UL30, reverse primer & 5'-CCA GCG GGT GTG AAT AAA AT-3' \\
\hline ChHV5 UL30, hydrolysis probe & $\begin{array}{l}\text { 5'-6-FAM-TGG CCA TCA-ZEN-AGC } \\
\text { TGA CGT GCA-3' }\end{array}$ \\
\hline C. mydas $\beta$-actin, forward primer & 5'-TGG TAC AGT CTC CCA TTC CA-3' \\
\hline C. mydas $\beta$-actin, reverse primer & 5'-AGG CAT ACA GGG ACA ACA CA-3' \\
\hline C. mydas GAPDH, forward primer & 5'-TCT GGG ATA GGT TGG GAG TC-3' \\
\hline C. mydas GAPDH, reverse primer & 5'-TCC TAG GCG ATA CTG CCT CT-3' \\
\hline
\end{tabular}


gene has a molar mass of $2.06 \times 10^{6} \mathrm{~g} \mathrm{~mol}^{-1}$. The plasmid was diluted in nuclease-free water (Qiagen) to yield $2.92 \times 10^{10}$ copies $\mu^{-1}$. Ten-fold serial dilutions of the diluted plasmid were used as qPCR templates to generate a standard curve, and were included in each run of the qPCR assay.

\section{qPCR reaction conditions and data interpretation}

Quantitative PCR reactions $(20 \mu \mathrm{l})$ were conducted in 96-well, $0.2 \mu \mathrm{l}$ PCR plates (Agilent Technologies) containing $10 \mu \mathrm{l}$ SensiFAST ${ }^{\mathrm{TM}}$ Probe Lo-ROX (Bioline), $0.8 \mu \mathrm{l}(0.32 \mu \mathrm{M})$ each of forward and reverse ChHV5 UL30 primers (IDT), $0.2 \mu \mathrm{l}(0.32 \mu \mathrm{M})$ of fluorescent probe (IDT), and $8.2 \mu \mathrm{l}$ genomic or plasmid DNA. All qPCR reactions were carried out using a MX3000 qPCR instrument (Stratagene) and the following reaction conditions: $10 \mathrm{~min}$ at $95^{\circ} \mathrm{C}$ (polymerase activation step), and 40 cycles each of $30 \mathrm{~s}$ at $95^{\circ} \mathrm{C}$ (denaturation step), $1 \mathrm{~min}$ at $55^{\circ} \mathrm{C}$ (primer annealing step), and $1 \mathrm{~min}$ at $72^{\circ} \mathrm{C}$ (elongation step). Samples and plasmid DNA standards were assayed in duplicate along with 4 no-template controls (nuclease-free distilled water; Qiagen). Extensive laboratory precautions, as outlined in the MIQE guidelines (Bustin et al. 2009), were taken to avoid assay contamination by genomic or plasmid DNA. Quantitative PCR data were analyzed with the Stratagene MXPro qPCR software (Agilent Technologies, Version 3.2). Tested samples were considered positive if duplicates had an average copy number equal to or higher than the assay's analytical limit of detection (LOD). Using the coefficient of determination $\left(\mathrm{R}^{2}\right)$ values, reaction efficiency and precision were calculated for all qPCR assays. To help increase $\mathrm{C}_{\mathrm{q}}$ value accuracy, an adaptive baseline threshold was generated for each assay run via MXPro software. Regression analysis of the standard curve (Larionov et al. 2005) was used to determine the number of ChHV5 DNA copies for each C. mydas DNA sample. ChHV5 UL30 copy numbers were calculated per microgram of gDNA extracted from each biological sample.

\section{ChHV5 UL30 qPCR assay validation}

qPCR efficiency and precision

To determine the ChHV5 UL30 qPCR assay efficiency and precision, 3 separate plasmid dilution series containing 3 to $3 \times 10^{10}$ copies were con- structed as described above and each curve was tested in replicates of $10 . \mathrm{R}^{2}$ values were calculated using $\mathrm{C}_{\mathrm{q}}$-values among plasmid curves and runs. Efficiency values were calculated using the formula $\mathrm{E}=10^{(-1 / \text { slope })}$ and the slope of each standard curve, with ideal assay efficiency at $100 \%$ and target efficiency between 90 and $110 \%$. The $\mathrm{C}_{\mathrm{q}}$ of each dilution was plotted, and data were fitted to a straight line to determine the linear dynamic range of each curve.

\section{Sensitivity and specificity}

Here, the ChHV5 UL30 qPCR assay's lower LOD was determined by applying qPCR to 42 qPCR replicates of low gene copy number $(1,5,50$, and 500 copies) plasmid DNA. Analytical specificity was determined by testing samples from 3 herpesviruses for cross-reactivity with our qPCR primers and probe: alcelaphine herpesvirus 1 (AlHV-1), a gammaherpesvirus in the genus Rhadinovirus (McGeoch et al. 2005); phocine herpesvirus 1 (PhHV-1), an alphaherpesvirus in the genus Varicellovirus; and phocine herpesvirus 2 (PhHV-2), a gammaherpesvirus in the genus Percavirus (Maness et al. 2011). No other sea turtle herpesvirus isolates were available for testing for assay cross-reactivity, but multiple sequence alignment against similar gene segments of other known sea turtle herpesviruses was performed using BLAST software (Altschul et al. 1990). Specifically, the $401 \mathrm{bp}$ ChHV5 UL30 consensus sequence used in this study was tested against available segments of the DNA polymerase gene of lung-eye-tracheaassociated herpesvirus (LETV: GenBank EU006876.1), loggerhead orocutaneous herpesvirus (LOCV; GenBank EU004544.1, EU004543.1, EU004542.1), and loggerhead genital-respiratory herpesvirus (LGRV; GenBank AB047545.1). Additional ChHV5 UL30 qPCR assay specificity was conferred via qPCR testing of biological samples collected from a captiveraised green turtle from a well-established, captive turtle collection in which FP has not been documented, as well as samples from 2 adult female freshwater turtles (T. scripta elegans).

\section{Repeatability}

Repeatability of the ChHV5 UL30 assay was determined by a single person using qPCR to test 3 ChHV5 DNA-positive samples each of FP, nontumored skin, blood, plasma, urine, and cloacal swab 
samples spanning the qPCR assay linear operating range on the Stratagene platform (Friedman et al. 2014). Samples were tested in replicates of 8 , and an intra-assay coefficient of variation (CV) of 0 to $20 \%$ was considered acceptable (Pfaffl 2004).

\section{Sequence analysis}

To confirm ChHV5 UL30 qPCR assay results, 30 randomly selected ChHV5 DNA-positive qPCR products constituting approximately $33 \%$ of the ChHV5 DNA-positive qPCR products were sequenced using Sanger sequencing technology (Genewiz) and $5 \mu \mathrm{l}$ of $5 \mu \mathrm{M}$ forward ChHV5 UL30 primer. Selected qPCR products were purified with the QIAquick Gel Extraction Kit (Qiagen), and the sequences obtained were compared to those deposited in the National Center for Biotechnology Information GenBank database using BLAST software (Altschul et al. 1990). Aligned sequences with $\geq 97 \%$ identity to the sample sequence were considered a match.

\section{Statistical analysis}

For each of the 3 study groups, the number of ChHV5 DNA-positive assays was enumerated according to sample type, and average ChHV5 DNA copy number (number of ChHV5 DNA copies $\mu \mathrm{g}^{-1}$ sample) and gDNA concentration ( $\mu \mathrm{g}$ gDNA $\mu l^{-1}$ ) were calculated for each sample type in each group. Average ChHV5 DNA copy numbers in each group were tested for normality via the Shapiro-Wilk test, and most data were non-normally distributed, likely due to small sample sizes. Thus, for consistency, the Kruskal-Wallis test for non-parametric data (with $\alpha$ set at 0.05) was used to compare the average ChHV5 DNA copy numbers between the 3 study groups for blood, non-tumored skin biopsies, urine, and cloacal swab samples. Post hoc pairwise comparisons were performed on statistically significant results using the Mann-Whitney $U$-test for non-parametric data with a Bonferroni correction. FP tumor, plasma, and fecal samples were not analyzed in this way due to a lack of sufficient sample sizes in the 3 study groups. Additionally, for each sample type, data from Groups $\mathrm{B}$ and $\mathrm{C}$ were combined, and the averages were compared to the average copy numbers from Group A using the 2-tailed Mann-Whitney $U$-test for nonparametric data with $\alpha$ set at 0.05. This analysis allowed us to effectively evaluate differences in the average viral copy numbers between FP+ and tumor- free turtles. The measure of agreement between various biologically related sample types was calculated using the un-weighted Kappa statistic: relationships were assessed between blood and urine, blood and non-tumored skin biopsies, urine and cloacal swabs, and whole blood and plasma samples. Statistical analyses were performed using IBM SPSS Statistics for MacIntosh, Version 22.0.

\section{Ethics statement}

This research was conducted in accordance with institutional, national, and international guidelines concerning the use of animals in research and the sampling of endangered species. Specifically, this research was conducted with the approval of the University of Georgia Office of the Vice President for Research, Institutional Animal Care and Use Committee, Permit A2012 10-011-Y1-A0, and with USA state permits to collect, transport, and store biological samples from green turtles: a scientific collecting permit (No. 29-WJH-13-44) and a Special Purpose Importation permit (No. S2-WJH-13-2) from the Georgia Department of Natural Resources, Wildlife Resources Division; and a Marine Turtle Permit (No. 149) and authorization to receive and/or transport sea turtle biological samples from the Florida Fish and Wildlife Conservation Commission.

\section{RESULTS}

\section{qPCR assay validation and optimization}

Reaction efficiency, coefficients of determination, and linear dynamic range

The ChHV5 plasmid standard curves (e.g. Fig. S1 in the Supplement at www.int-res.com/articles/suppl/ n028p135_supp.pdf) had reaction efficiencies ranging from 94.2 to $111.4 \%$ (average $\pm \mathrm{SD}=97.53 \pm 5.62$ ), and coefficients of determination $\left(\mathrm{R}^{2}\right)$ ranging from 0.924 to 0.999 (average $\pm \mathrm{SD}=0.986 \pm 0.02$; Dataset $\mathrm{S} 1$ in the Supplement). The assay was determined to have a dynamic range between 50 and $\sim 2$ billion gene copies, based on reaction efficiency.

\section{Sensitivity and specificity}

The qPCR assay was able to detect low plasmid copy numbers ranging from $16.7 \%$ (7/42) for 1 
gene copy, $50 \%(21 / 42)$ for 5 gene copies, $85.7 \%$ (36/42) for 50 gene copies, and $100 \%(42 / 42)$ for 500 gene copies (Dataset S2 in the Supplement). Based on a $50 \%$ certainty cutoff, as defined by the OIE (World Organization for Animal Health) (OIE 2009), the minimum LOD of our qPCR assay was 50 gene copies per reaction. Therefore, only unknown samples whose average quantities were $\geq 50$ gene copies were considered positive. Presence of amplifiable DNA was demonstrated by amplification of Chelonia mydas $\beta$-actin and GAPDH gene segments in all samples included in the study. The primers and probe developed for qPCR were specific to the ChHV5 DNA polymerase (UL30) gene target: qPCR primers were unable to amplify DNA from the related herpesviruses (BHV3, PhHV-1, PhHV-2) assayed, and multiple sequence alignment (BLAST; Altschul et al. 1990) revealed that the nucleotide sequence within the span of the qPCR product does not align at all with LETV, LOCV, or LRGV at the nucleotide level. At the translated amino acid level, the ChHV5 UL30 consensus sequence aligns $99 \%$ with ChHV5 (GenBank AY646891.1), versus 70\% with LGRV, $69 \%$ with LOCV, and only $68 \%$ with LETV. These data indicate that the qPCR primers and probe used in this study would not amplify gene segments of any known sea turtle herpesvirus other than ChHV5. Template controls (i.e. certified nuclease-free distilled water; Qiagen) and biological controls (i.e. known negative samples from captive-reared green and freshwater turtles) did not amplify (Dataset S3 in the Supplement). Additionally, melt-curve analysis showed a single amplified product when we used SYBR green I chemistry (Bioline) to test our chosen primers with the qPCR assay (Fig. S2 in the Supplement; Bustin \& Nolan 2004). The amplified and sequenced PCR product was identified as chelonid herpesvirus 5 (GenBank HQ878327.2; $100 \%$ pairwise identity; Altschul et al. 1990).

Repeatability

For each biological sample type that tested positive for ChHV5 DNA, the overall average CVs for samples of relatively low, medium, and high viral DNA copy number were $12.41 \%$ for FP tumors, $13.97 \%$ for non-tumored skin, $14.42 \%$ for blood, $13.68 \%$ for plasma, $18.18 \%$ for urine, and $13.86 \%$ for cloacal swabs (Dataset S4 in the Supplement).

\section{Viral DNA detection in biological samples}

Biological samples were collected from 67 rehabilitating green turtles: Group A (turtles with clinical signs of $F P, n=23$ ), Group B (turtles with a history of FP but with no clinical signs, $\mathrm{n}=13$ ), and Group C (turtles with no known history of FP, $\mathrm{n}=31$ ). A total of 351 DNA extracts from 67 individual sea turtles were screened for ChHV5 by qPCR (Table S1 in the Supplement). In Group A, 21/23 turtles $(91.3 \%)$ had at least 1 ChHV5 DNApositive sample via $\mathrm{qPCR}_{i}$ FP tumor samples were not available for the 2 turtles with no ChHV5 DNA-positive samples. Overall, of the 44 turtles that did not have grossly visible FP at the time of sampling, 20 turtles had at least 1 ChHV5 DNApositive tissue, blood, or urine sample ( 7 in Group $B_{i} 13$ in Group C), and 24 had all samples negative for ChHV5 DNA via qPCR. Table 2 shows average extracted gDNA concentrations ( $\mu \mathrm{g}$ gDNA $\mu^{-1}$ ), percentage of positive samples, and ChHV5 DNA copy numbers (number of ChHV5 DNA copies $\mu^{-1}$ sample) for each sample type within the 3 study groups. ChHV5 DNA was not identified in oral swab or fecal samples. No significant differences in ChHV5 DNA copy numbers between the 3 study groups were found for whole blood, skin biopsy, or cloacal swab samples. Statistical comparisons between study groups were not possible for urine samples due to small sample sizes. Some samples were not available for some turtles; qPCR data for samples from individual turtles are detailed in Table S1 in the Supplement. Measures of agreement between sample types within individual turtles are reported in Table 3.

\section{qPCR product sequence data}

Sequence data were obtained for 30 samples that were positive for ChHV5 DNA via qPCR: 6 FP tumor samples, 6 non-tumored skin samples, 7 whole blood samples, 2 plasma samples, 4 urine samples, and 5 cloacal swab samples. All sequences obtained were from biological samples taken from different individual turtles (Table S1 in the Supplement); multiple sample types were not sequenced from the same turtle. ChHV5 DNA-positive samples of FP tumors, non-tumored skin, blood, plasma, urine, and cloacal swab samples matched several aligned DNA sequences with $\geq 97 \%$ identity; GenBank accession numbers are provided in Table S2 in the Supplement. 


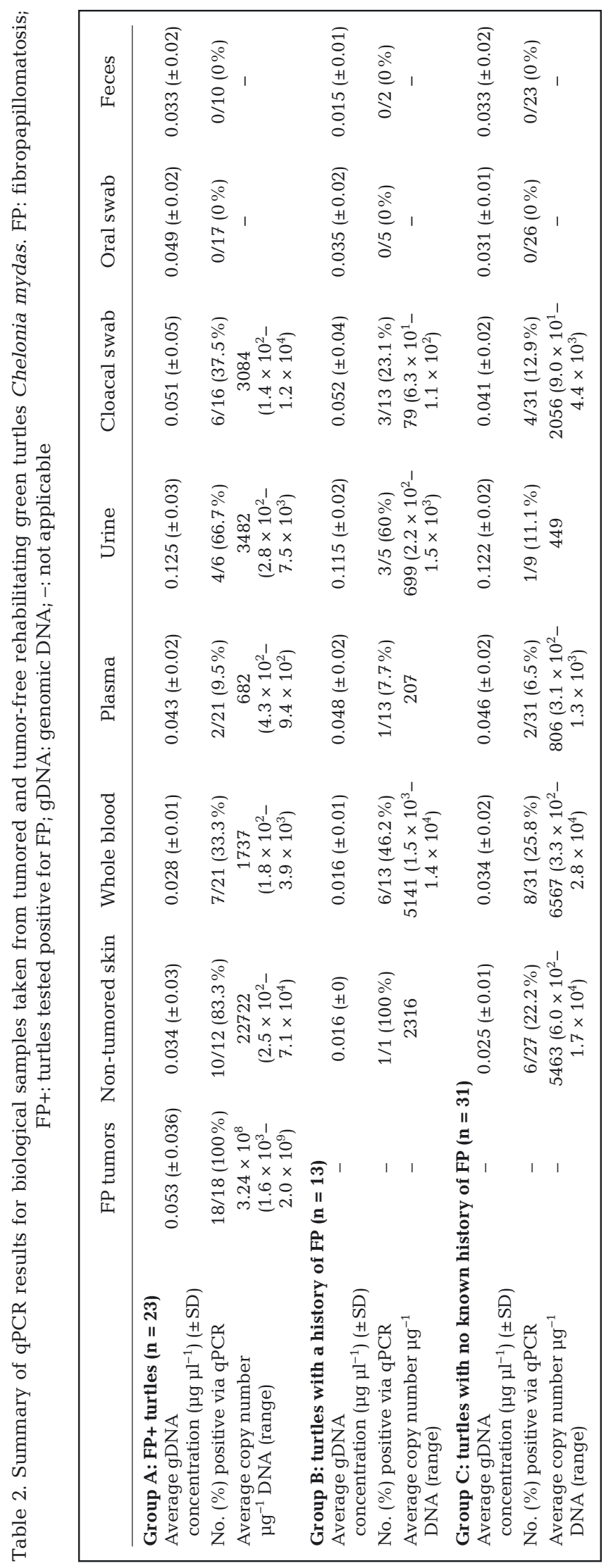

\section{DISCUSSION}

Via qPCR, ChHV5 DNA was detected in FP tumors, non-tumored skin, blood, urine, cloacal swabs, and plasma sampled from green turtles in all 3 study groups. Although several previous studies have identified ChHV5 DNA in FP tumors and non-tumored skin (Lackovich et al. 1999, Lu et al. 2000, Quackenbush et al. 2001, Page-Karjian et al. 2012, AlfaroNúñez et al. 2014), here we provide novel evidence for the presence of ChHV5 DNA in blood, urine, cloacal swabs, and plasma from turtles with and without FP tumors. This study provides critical information for a deeper understanding of the complex ChHV5 pathogenesis in symptomatic and asymptomatic turtles.

ChHV5 DNA copy numbers in FP tumors were several orders of magnitude greater than those seen in any other sample types; this observation lends further support to the hypothesis that ChHV5 is highly associated with the formation of FP tumors. Our finding that $83.3 \%$ of non-tumored skin samples from FP+ turtles (turtles with FP) tested positive for ChHV5 DNA is similar to a previous study, in which $88 \%$ of $\mathrm{FP}+$ green turtles had non-tumored skin samples that tested positive for ChHV5 DNA by qPCR (AlfaroNúñez et al. 2014). Our findings that skin samples from $7 / 28(25 \%)$ of tumor-free turtles were positive for ChHV5 DNA via qPCR is also similar to the results of another study, in which $32.4 \%$ of skin samples from tumor-free turtles were positive for ChHV5 DNA via nested PCR (Page-Karjian et al. 2012).

Circulating ChHV5 DNA (DNAemia) was observed in whole blood samples taken from turtles in all 3 study groups, and numbers of positive samples were similar between the 3 groups (Table 2), as well as between FP+ (Group $A_{i} 7 / 21$ or $33.3 \%$ ) and tumorfree turtles (Groups B and $C_{i} 14 / 44$ or $31.8 \%$ ). If linked to infectious virus, the presence of DNAemia could suggest a critical mechanism for viral transport to the skin from sites of initial infection or latency (or vice versa). The average ChHV5 DNA copy number in skin biopsy samples from tumor-free turtles (Groups B and C) is slightly less than that of whole blood samples from tumor-free turtles, and the Kappa statistic $(K=0.44)$ for whole blood and skin biopsy samples suggests that skin and blood viral DNA loads are related. These data indicate that in subclinical turtles, DNAemia may be related to the presence of ChHV5 DNA in the skin, and therefore the multi-centric nature of FP tumors may be attributable to circulating virus in infected cells within the bloodstream (e.g. circulating tumor precursor cells, lymphocytes). 
Table 3. Measures of agreement between qPCR data from various biological sample types for individual green turtles Chelonia mydas. +, -: positive, negative for ChHV5; n: number of individuals in each pair of samples. (Cohen's) Kappa statistic (K) is a measure of diagnostic agreement between 2 tests. $\mathrm{K}$ statistic values range from 0 to 1 , with $\mathrm{K}<0.2$ indicating poor agreement; $\mathrm{K}=0.2-0.3$ indicating fair agreement; $\mathrm{K}=0.4-0.59$ indicating moderate agreement; $\mathrm{K}=0.6-0.79 \mathrm{indicating}$ good agreement; and $\mathrm{K}=0.8-1.0$ indicating very good agreement (Kraemer et al. 2004)

\begin{tabular}{|lccccccc|}
\hline Two sample types compared & $\mathrm{n}$ & $+/+$ & $-/-$ & $+/-$ & $-/+$ & Level of agreement (\%) & Kappa ( \pm SE; 90\% CI) \\
\hline Blood/urine & 18 & 6 & 13 & 0 & 0 & 100 & $1( \pm 1 ; 1-1)$ \\
Blood/non-tumored skin & 38 & 8 & 20 & 1 & 9 & 73.7 & $0.44( \pm 0.15 ; 0.15-0.74)$ \\
Blood/plasma & 65 & 5 & 44 & 16 & 0 & 75.4 & $0.3( \pm 0.15 ; 0-0.6)$ \\
Urine/cloacal swabs & 20 & 3 & 10 & 5 & 2 & 65 & $0.22( \pm 0.24 ; 0-0.69)$ \\
\hline
\end{tabular}

Overall, ChHV5 DNA was detected in only 5 plasma samples in relatively low DNA copy numbers, and the low Kappa statistic between whole blood and plasma samples indicates poor agreement. These findings suggest that, like many other herpesviruses (e.g. equine herpesvirus-1), ChHV5 is strongly cellassociated and does not replicate outside of host cells while in the bloodstream (Lunn et al. 2009). This observation is further supported by the fact that all 5 plasma samples that were positive for ChHV5 DNA by qPCR were visibly hemolyzed (pink-tinged) and presumed to have contained ruptured blood cells. Heparin was chosen as the anticoagulant in this study because reptilian blood exhibits prolonged clot formation due to low intrinsic thromboplastin activity and a strong natural circulating antithrombin factor; therefore, plasma is generally preferred over serum in reptiles (Cray \& Tatum 1998, Campbell 2012). Heparin has been shown to inhibit PCR when plasma is collected $>6 \mathrm{~h}$ after venipuncture; however, in this study plasma was collected within $10 \mathrm{~min}$ of venipuncture and therefore anticoagulant inhibition of PCR is not expected to have occurred (Lam et al. 2004).

Four of $6(66.7 \%)$ of the FP+ turtles (Group A) had urine samples that were positive for ChHV5 DNA by qPCR, and $4 / 14(28.6 \%)$ of the tumor-free turtles (Groups B and C) had ChHV5 DNA-positive urine samples. These findings show that symptomatic and asymptomatic ChHV5 DNA-positive turtles are capable of shedding ChHV5 DNA into their environment via urine, and suggests, for the first time, that turtles are capable of shedding viral DNA by a route other than via infected skin cells. A related sea turtle herpesvirus, LETV, was shown to remain infectious in seawater for up to $120 \mathrm{~h}$ (Curry et al. 2000). Thus, ChHV5 DNA presence in urine represents a potential route of environmental ChHV5 transmission and warrants further investigation, including the documentation of ChHV5 in water and determining how long ChHV5 can persist outside the host within the marine environment. Statistical comparison between the study groups was not possible due to small sample sizes; however, the average viral DNA copy number in the urine of FP+ turtles (Group A) is an order of magnitude larger than that observed in Groups B or C. This suggests that FP+ turtles are likely to shed relatively greater quantities of ChHV5 DNA in their urine than are tumor-free turtles. The perfect level of agreement between whole blood and urine samples $(\mathrm{K}=1)$ implies that turtles with moderate to high viral loads circulating in their blood (DNAemia) may be more likely to shed ChHV5 DNA in their urine, although our conclusions are limited by the small number of urine samples available and the fact that urine samples were not available for all turtles with high levels of ChHV5 DNAemia (and vice versa). If the virus infects kidney epithelium, viral progeny could be released to the urine through kidney epithelial damage, thereby allowing infected cells to pass into the kidney filtrate. Another explanation is that the kidneys and/or urinary bladder epithelium are sites of persistent ChHV5 infection, in which case the urine samples could be ChHV5 DNA-positive due to the presence of sloughed, infected epithelial cells. A less likely source of sloughed, infected epithelial cells in these urine samples is the cloacal epithelium, since the level of agreement is low $(K=0.22)$ between urine and cloacal swabs taken concurrently from the same individual. More research is needed to determine the precise mechanism by which ChHV5 DNA enters the urine. Although one benefit of working with rehabilitating turtles is that certain samples are more easily collected, sea turtle urine can be difficult to obtain even in controlled settings. This fact makes the data presented here all the more valuable as an indication of the natural history of ChHV5associated disease, and as a basis for future research.

For the cloacal swab samples, a clear trend was observed in the proportion of qPCR-positive samples in the 3 study groups: $44.4 \%$ in the FP+ turtles (Group A), 23.1\% in turtles with a history of FP 
(Group B), and only $12.9 \%$ in turtles with no known history of FP (Group C). The relatively low prevalence of ChHV5 DNA in cloacal swabs and the complete lack of ChHV5 DNA in fecal samples and oral swabs suggest that the positive qPCR results obtained in this study did not result from environmental contamination of samples. Future studies of ChHV5 in biological samples taken from wild-caught green turtles, however, should include simultaneous assessment of environmental samples for viral DNA, in addition to the biological samples to help ensure the absence of environmental contamination.

Using guidelines outlined by the World Organization for Animal Health (OIE 2009) and the minimum information for publication of qPCR experiments (Bustin et al. 2009), the qPCR assay presented here reliably detected and quantified ChHV5 DNA in various green turtle biological samples. The assay has high analytical sensitivity and specificity for ChHV5 DNA and is repeatable and robust. DNA-based PCR assays are not capable of determining if a disease agent or infection is viable and therefore function only as a proxy for an infectious organism. ChHV5 viral particles have been previously demonstrated via electron microscopy (EM) in FP tumor samples (Jacobson et al. 1991). The concentration of viruses has to be high enough in biological fluid samples to allow detection using EM, however, and tissue samples must be large enough to contain area(s) of infection and permit EM preparation (Goldsmith \& Miller 2009). In the current study, fluid sample volumes were too small to permit detection of viral particles via EM, and skin biopsy samples were too small to permit both DNA extraction and EM preparation. Via BLAST software (Altschul et al. 1990), 16/20 (80\%) GenBank sequences that were used to develop the consensus sequence on which our qPCR was based were matched with $\geq 97 \%$ identity to our qPCR product sequences. This verifies the assay's ability to accurately isolate and amplify the targeted ChHV5 DNA sequences, and indicates its high level of gene target specificity.

As molecular diagnostics become more affordable, sea turtle health experts can use qPCR to monitor ChHV5 gene copies and thereby detect early signs of viral presence in blood, urine, and tissue samples. Thus, using this qPCR will allow researchers to evaluate quantifiable ChHV5 DNA loads and how they relate to free-ranging green turtle disease and mortality, immunity, and certain environmental variables such as water temperature and quality. Subclinical ChHV5 infections are of great epidemiological importance, as they may provide a reservoir that allows the disease to persist even in smaller groups of turtles, and can constitute major sources of viral dissemination through a population (Herbst et al. 2008). If ChHV5 infection is found to be highly prevalent in healthy-appearing turtles, it suggests that FP outbreaks may be more influenced by environmental or host factors affecting disease expression than they are by factors affecting viral transmission (Herbst et al. 2008). Further studies evaluating the kinetics of ChHV5 DNA loads in blood, urine, and skin samples from turtles prior to, during, and after FP tumor development are needed to help determine how quantifiable ChHV5 DNA loads relate to free-ranging green turtle FP disease and certain environmental variables. Given that green turtles are listed as a threatened species by the International Union and Conservation of Nature and the governments of many nations, an enhanced ability to assess the health status of captive and free-ranging sea turtles will enable biologists and veterinarians to better manage population restoration and rehabilitation actions.

Acknowledgements. This research was supported by grants from the American Association of Zoo Veterinarians Wild Animal Health Fund, the Sophie Danforth Conservation Biology Fund, and the Sigma Xi Grants-in-Aid of Research Program. Funding for laboratory materials was generously provided by the Department of Pathology and the Infectious Diseases Laboratory of the University of Georgia, College of Veterinary Medicine. The authors thank Steven Roberts, Lisa Crosson, and Jian Zhang for their help with qPCR assay development and manuscript review. We thank Charles Manire, Richard Moretti, Doug Mader, Steven Nelson, Caitlin Greene, Nicole Montgomery, Amy Hupp, Michelle Kaylor, Rachel Thomas, Rachel Sommer, and Bette Zirklebach for collecting and providing samples from rehabilitating turtles. Zhen Fu and Alvin Camus provided access to important laboratory equipment. Jeremiah Saliki provided herpesvirus samples for analysis of diagnostic specificity, as well as valuable advice on herpesvirus biology. Biological samples for diagnostic specificity evaluation were provided by Stephen Divers. Jim Wellehan provided helpful comments on study design and methodology. Adriana Weil and Kebora Weir provided laboratory assistance. We thank Meghan Koperski for assistance with permits, and R. Keith Harris for moral support. We gratefully acknowledge the anonymous reviewers of this paper for providing constructive feedback, thereby improving the manuscript.

\section{LITERATURE CITED}

Ackermann M, Koriabine M, Hartmann-Fritsch F, de Jong PJ and others (2012) The genome of chelonid herpesvirus 5 harbors atypical genes. PLoS ONE 7:e46623

Adams MJ, Carstens EB (2012) Ratification vote on taxonomic proposals to the International Committee on Taxonomy of Viruses. Arch Virol 157:1411-1422

Aguirre AA, Lutz PL (2004) Marine turtles as sentinels of 
ecosystem health: Is fibropapillomatosis an indicator? EcoHealth 1:275-283

- Alfaro-Núñez A, Gilbert MTP (2014) Validation of a sensitive PCR assay for the detection of chelonid fibropapillomaassociated herpesvirus in latent turtle infections. J Virol Methods 206:38-41

Alfaro-Núñez A, Bertelsen MF, Bojesen AM, Rasmussen I, Zepeda-Mendoza L, Olsen MT, Gilbert MTP (2014) Global distribution of chelonid fibropapilloma-associated herpesvirus among clinically healthy sea turtles. BMC Evol Biol 14:206-216

Altschul SF, Gish W, Miller W, Myers EW, Lipman DJ (1990) Basic local alignment search tool. J Mol Biol 215:403-410

Balazs GH (1989) Fibropapillomas in Hawaiian green turtles. Mar Turtle Newsl 39:1-3

Bustin SA, Nolan T (2004) Pitfalls of quantitative real-time reverse-transcription polymerase chain reaction. J Biomol Tech 15:155-166

Bustin SA, Benes V, Garson JA, Hellemans J and others (2009) The MIQE guidelines: minimum information for publication of quantitative real-time PCR experiments. Clin Chem 55:611-622

Campbell T (2012) Clinical chemistry of reptiles. In: Thrall MA, Weiser G, Allison RW, Campbell TW (eds) Veterinary hematology and clinical chemistry. Wiley, Ames, IA, p 599-606

> Chaloupka M, Balazs GH, Work TM (2009) Rise and fall over 26 years of a marine epizootic in Hawaiian green sea turtles. J Wildl Dis 45:1138-1142

Cray C, Tatum LM (1998) Applications of protein electrophoresis in avian diagnostics. J Avian Med Surg 12:4-10

> Curry SS, Brown DR, Gaskin JM, Jacobson ER and others (2000) Persistent infectivity of a disease-associated herpesvirus in green turtles after exposure to seawater. J Wildl Dis 36:792-797

- Davison AJ, Eberle R, Ehlers B, Hayward GS and others (2009) The order Herpesvirales. Arch Virol 154:171-177

> Duarte A, Faisca P, Loureiro NS, Rosado R, Gill S, Pereira N, Tavares L (2012) First histological and virological report of fibropapilloma associated with herpesvirus in Chelonia mydas at Principe Island, West Africa. Arch Virol 157: 1155-1159

- Ene A, Su M, Lemaire S, Rose C and others (2005) Distribution of chelonid fibropapillomatosis-associated herpesvirus variants in Florida: molecular genetic evidence for infection of turtles following recruitment to neritic developmental habitats. J Wildl Dis 41:489-497

Friedman CS, Wight N, Crosson LM, White SJ, Strenge RM (2014) Validation of a quantitative PCR assay for detection and quantification of 'Candidatus Xenohaliotis californiensis'. Dis Aquat Org 108:251-259

Gärtner B, Preiksaitis JK (2010) EBV viral load detection in clinical virology. J Clin Virol 48:82-90

Goldsmith CS, Miller SE (2009) Modern uses of electron microscopy for detection of viruses. Clin Microbiol Rev 22:552-563

Herbst LH (1994) Fibropapillomatosis of marine turtles. Annu Rev Fish Dis 4:389-425

Herbst LH, Jacobson ER, Moretti R, Brown T, Sundberg JP, Klein PA (1995) Experimental transmission of green turtle fibropapillomatosis using cell-free tumor extracts. Dis Aquat Org 22:1-12

> Herbst LH, Jacobson ER, Klein PA, Balazs GH, Moretti R, Brown T, Sundberg JP (1999) Comparative pathology and pathogenesis of spontaneous and experimentally induced fibropapillomas of green turtles (Chelonia mydas). Vet Pathol 36:551-564

Herbst LH, Lemaire S, Ene AR, Heslin DJ and others (2008) Use of baculovirus-expressed glycoprotein $\mathrm{H}$ in an ELISA developed to assess exposure to chelonid fibropapillomatosis-associated herpesvirus and its relationship to the prevalence of fibropapillomatosis in sea turtles. Clin Vaccine Immunol 15:843-851

Hirama S, Ehrhart LM (2007) Description, prevalence and severity of green turtle fibropapillomatosis in three developmental habitats on the east coast of Florida. Biol Sci 4:435-448

Huerta P, Pineda H, Aguirre A, Spraker T, Sarti L, Barragan A (2002) First confirmed case of fibropapilloma in a leatherback turtle (Dermochelys coriacea). In: Mosier A, Foley A, Brost B (eds) Proc 20th Ann Symp Sea Turtle Biol Cons. US Dept Commerce NOAA-SEFSC, Miami, p 193

Jacobson ER, Buergelt C, Williams B, Harris RK (1991) Herpesvirus in cutaneous fibropapillomas of the green turtle Chelonia mydas. Dis Aquat Org 12:1-6

Kraemer HC, Periyakoil VS, Noda A (2004) Kappa coefficients in medical research. In: D'Agostino RB (ed) Tutorials in biostatistics, Vol 1: Statistical methods in clinical studies. John Wiley \& Sons, New York, NY, p 85-105

Lackovich JK, Brown DR, Homer BL, Garber RL and others (1999) Association of herpesvirus with fibropapillomatosis of the green turtle Chelonia mydas and the loggerhead turtle Caretta caretta in Florida. Dis Aquat Org 37 : 89-97

Lam NYL, Rainer TH, Chiu RWK, Lo YMD (2004) EDTA is a better anticoagulant than heparin or citrate for delayed blood processing for plasma DNA analysis. Clin Chem 50:256-257

> Larionov A, Krause A, Miller W (2005) A standard curve based method for relative real time PCR data processing. BMC Bioinformatics 6:62

> Lu Y, Nerurkar VR, Aguirre AA, Work T, Balazs G, Yanagihara R (1999) Establishment and characterization of 13 cell lines from a green turtle (Chelonia mydas) with fibropapillomas. In Vitro Cell Dev Biol Anim 35:389-393

> Lu Y, Wang Y, Yu Q, Aguirre AA, Balazs GH, Nerurkar VR, Yanagihara R (2000) Detection of herpesviral sequences in tissues of green turtles with fibropapilloma by polymerase chain reaction. Arch Virol 145:1885-1893

Lunn DP, Davis-Poynter N, Flaminio MJBF, Horohov DW, Osterrieder K, Pusterla N, Townsend HGG (2009) Equine herpesvirus-1 consensus statement. J Vet Intern Med 23: 450-461

> Mackay IM (2004) Real-time PCR in the microbiology laboratory. Clin Microbiol Infect 10:190-212

Maness HTD, Nollens HH, Jensen ED, Goldstein T and others (2011) Phylogenetic analysis of marine mammal herpesviruses. Vet Microbiol 149:23-29

McGeoch DJ, Gatherer D, Dolan A (2005) On phylogenetic relationships among major lineages of the Gammaherpesvirinae. J Gen Virol 86:307-316

> McGeoch DJ, Rixon FJ, Davison AJ (2006) Topics in herpesvirus genomics and evolution. Virus Res 117:90-104

> Moore MK, Work TM, Balazs GH, Docherty DE (1997) Preparation, cryopreservation, and growth of cells prepared from the green turtle (Chelonia mydas). Methods Cell Sci 19:161-168

OIE (World Organization for Animal Health) (2009) Manual of diagnostic tests for aquatic animals, $6^{\text {th }}$ edn. OIE, Paris 
Page-Karjian A, Torres F, Zhang J, Rivera S and others (2012) Presence of chelonid fibropapilloma-associated herpesvirus in tumored and non-tumored green turtles, as detected by polymerase chain reaction, in endemic and non-endemic aggregations, Puerto Rico. SpringerPlus 1:35-50

Page-Karjian A, Norton TM, Krimer P, Groner M, Nelson SE, Gottdenker NL (2014) Factors influencing survivorship in rehabilitating green sea turtles (Chelonia mydas) with fibropapillomatosis. J Zoo Wildl Med 45:507-519

Paillot R, Case R, Newton R, Nugent J (2008) Equine herpes virus-1: virus, immunity and vaccines. The Open Vet Sci J 2:68-91

Pfaffl MW (2004) Quantification strategies in real-time PCR. In: Bustin SA (ed) A-Z of quantitative PCR. International University Line, La Jolla, CA, p 87-112

Quackenbush SL, Casey RN, Murcek RJ, Paul TA and others (2001) Quantitative analysis of herpesvirus sequences from normal tissue and fibropapillomas of marine turtles with real-time PCR. Virology 287:105-111

Ritchie B (2006) Virology. In: Mader DR (ed) Reptile medicine and surgery. W.B. Saunders Co., Philadelphia, PA, p 391-417

Rozen S, Skaletsky HJ (2000) Primer3 on the WWW for general users and for biologist programmers. In: Krawetz $\mathrm{S}$, Misener S (eds) Bioinformatics methods and protocols: methods in molecular biology. Humana Press, Totowa, NJ, p 365-386

Editorial responsibility: Mark Hamann, Townsville, Queensland, Australia
Stanton JJ, Zong JC, Eng C, Howard L and others (2013) Kinetics of viral loads and genotype analysis of elephant endotheliotropic herpesvirus-1 infection in captive Asian elephants (Elephas maximus). J Zoo Wildl Med 44:42-54

Stratagene (2004) Introduction to quantitative PCR: methods and application guide. Stratagene, La Jolla, CA

Tristan T, Shaver DJ, Kimbro J, deMaar T, Metz T, George J, Amos A (2010) Identification of fibropapillomatosis in green sea turtles (Chelonia mydas) on the Texas coast. J Herp Med Surg 20:109-112

Williams EH, Bunkley-Williams L, Peters EC, PintoRodriguez B and others (1994) An epizootic of cutaneous fibropapillomas in green turtles Chelonia mydas of the Caribbean: part of a panzootic? J Aquat Anim Health 6: 70-78

Work TM, Dagenais J, Balazs GH, Schumacher J and others (2009) In vitro biology of fibropapilloma-associated herpesvirus and host cells in Hawaiian green turtles (Chelonia mydas). J Gen Virol 90:1943-1950

Work TM, Dagenais J, Balazs GH, Schettle N, Ackermann $M$ (2015) Dynamics of virus shedding and in situ confirmation of chelonid herpesvirus 5 in Hawaiian green turtles with fibropapillomatosis. Vet Pathol, doi:10.1177/ 0300985814560236

Yamamoto Y, Morooka M, Hashimoto S, Ihra M, Yoshikwa T (2014) Analysis of the shedding of $3 \beta$-herpesviruses in urine and saliva of children with renal disease. J Med Virol 86:505-511

Submitted: February 6, 2015; Accepted: June 19, 2015 Proofs received from author(s): August 13, 2015 